\title{
農村人口の動態と家族の変容
}

\section{松下 敬一郎 \\ Changes in Population and the Family in Rural Areas}

\author{
Keiichiro Matsushita (Ryukoku University)
}

Rural communities have been influenced by postwar reforms, rapid economic growth in industrial areas and agricultural policies. Rural families, heavily dependent on agricultural production earlier, responded to these changes by sending excess labor force to urban and industrial areas. Demographic changes in fertility and mortality in rural areas corresponded with their counterparts in urban areas. However, migration and nuptiality showed different trends: 1) rural-urban migration was phenomenal in the 1950's and the 1960's; 2) the proportion of single males has increased more in rural areas. The aging of the rural population advanced more rapidly as the result of rural-urban migration. Nevertheless, patrilineally extended families were kept intact in rural areas unless economic opportunities were scarce in the area for family heirs.

Increase in human capital investment and in opportunity cost of household production, intrduction of timesaving home appliances, social security and high cost of living has affected decision making in marriage and childbirth in general. In rural areas, however, where extended families are common, joint produc- tion and division of labor are more effective than in small nuclear households. Farm households must increase labor productivity both in agriculture and household production in the course of rural development.

It is important to reconsider the population reproduction process in rural development. Household production, interaction among household members, inter-generational income transfers and family security are major characteristics of the family. Intergenerational cooperation and equity as well as a more attractive environment for women in labor force and child-rearing must be incorporated in rural development policy measures. In addition, these measures should be directed toward 1) locally characteristic and transitory aging population, 2) increase in unmarried male population, 3) decrease in population, and 4) enhancement of infrastructure for population reproduction. It is important to propose several policy options. Participation of family members not living in the rural area in a policy-making group may be helpful in formulating options as well as mobilizing their resources.
日本の農村社会は, 戦後の政治・経済の変化に対応 して，大きな变貌を遂げた，それは，人口の変動と家 族の変容をも含むものであった．戦後の民主化や 1950 年代に入ってからの高度経済成長は，その主因となる ものであった. 農村が都市や工業地域の後背地となる 一方で, 農業は産業政策から切り捨てられることなく 部分的に保護政策の対象となり，農家は兼業化するこ とで小規模経営を維持しながら所得増加を達成してき た. 基本法農政 - 国土計画 - 農地計画 - 山村振興 - 過 柾対策など，農業関連政策は少なからず農村社会に影

響を与えるものであった。

本論において, 人口の動態は, 出生・死亡・婚姻・ 移動といら狭義の人口動態と, 年龄構成の変化など人 口静態の変動といら広義の人口動態を含む. 出生力お
よび死亡水準については，若干の地域差がみられるも のの, 地域社会の変動あるいは活性化との関連は小さ い. 一方, 人口移動および婚姻は, 地域社会の変動あ るいは活性化によって大きな影響を受ける．家族の変 容には多様な側面が含まれるが，人口に異動が生じる と家族成員の組み合わせである世帯構成が変化する. 地域社会の变動により地域間に格差が生じると, 家族 はとれに対して柔軟に対応し，人口や世帯に変化が生 じる.

地域社会の変動あるいは活性化が人口の動態や家族 に変化をもたらす一方で，人口や家族は地域社会活性 化の制限条件となり，またその目標ともなり得る。戦 後の改革期は別としても, 高度経済成長期において, 農村社会が経済的, 政策的, あるいは文化的な外因の 
変化に対してやや受動的な対応を迫られた一面が確か にみられる. 農村社会が慣習的, 保守的で新しい文化 を生み出すことのできない地域であるかのような偏っ たイメージは漸く払拭されつつある。一方, 超高龄社 会をすでに迎えている中山間農村に执いては，地域経 済の活性化による雇用機会の確保が生産年齢人口の維 持に不可欠である. 人口の增堿を活性化の効果を示す 単純な一指標としてとりあげ，その変化に一喜一夏す る場合さえ生じているが, 地域社会の活性化のために 農村社会のもつ創造性を発揮することが今求められて いる.

\section{1. 背 景}

\section{（1）地域と農村・農業・農家}

地域は一般に地理空間的な広がりをもつが，農業的 な景観を示す空間を線引きすることによりほ添農村に 対応させることができる。もちろん，農村や地域とい っても，自然村にあたる農村集落から農村全体まで， あるいは旧村や地方自治体などの行政村といった使い 分けが必要である. 同じ市町村内の集落でも人口の年 龄構造や世帯の家族構成に多様な变化がみられる。こ の農村集落の多様性を活かしながら，あるい悵短を 補い合いながら，上り広範用な地域経済の活性化をめ ざす必要がある.

一般に, 地域社会の活性化の政策面に打惊体で あり，かつその対象となるのは地方自治体である．当 然のことながら，1）地域経済の一要素である農業,

2 ）地域人口の一部である農業人口，そして 3 ）一般 世帯と農家世帯（あるいは家族全体と農家）を峻別し て政策課題を検討する必要が生じる，農村といっても 専業農家群からなる「純」農村は限られた地域にしか みられなくなっており，農村社会の経済基盤は農業以 外の産業により多くを依存するよらになった，地域経 済の発展に㧊いて農業の発展は一つの構成要素にすぎ ないことを示している．農工間格差が拡大し都市への 人口流出が進む中, 農業生産性を上昇させるための農 村の基盤整備が実施され，農村社会を構成する農業的 要素が工業化されたり単純化された。農村社会におけ る生活様式の变化についても, その外観は都市に护け る变化に追随するものであった．政策的な農業保護の 下に，十分な国際競争力をもたないまま経済成長の恩 恵に浴していた農業および農村社会をとりまく経済環 境は大きく変化した，この変動の時期こそ農村社会の 重要性とその活性化そして農業の競争力について考兄 る好機となっている.
人口の再生産とは異なり, 農業人口の再生産は就職 と離職により継続される。人口移動および農家の兼業 化の中で, 新卒農業就職者の減少, 他産業への就業, 中高齢者の参入, 平均余命の増加と現就業者の加齢の ため農業就業人口は减少し高齢化した．兼業化とも関 㐿する農地の低い流動性は, イエの継続, 資産継承, 貸借慣行の特殊性など制度的要因からなる経済外部性 に影響を受けていた。農業保護と増加する農外就業機 会のなかで，小規模経営農家が国際競争力をもつ農業 労動生産性の向上と専業化を選択することは例外的で あった．兼業農家にとって二次的収入源としての農業 は不可欠であるが，地域経済からみると農地利用の面 で非効率な資源配分が進行した. 現在すでに高龄化し ている農業人口の再生産については, 農家を含めた農 企業と兼業農家について今後の併存状態の推移を見定 める必要がある。

家族も社会経済的な变化（戦後の改革, 民法改正, 高度経済成長，国際化，高齢化など）に影響を受けて いるが，都市に労働力人口を供給した農家は比較的緩 やかな変容を遂げた，日本人の価值観，意識，喍好

(選好構造), 関係づけなどは戦後大きく変化したが, 祖先崇拝をはじめ伝統的分野や祭りを維持しようとす ることなどの基底的な意識はあまり变わっていないよ らにみえる。また，血縁の紏や心情もそれ汪ど大きく 変化していないように思わ机る. しかし, 家族をとり まく環境が根本的に, そして急速に变化したことは明 らかである。都市に転出した人口が主に核家族世帯を 形成していく一方, 転出元の農村家族は直系払大家族 世帯を維持した．地域によっては，特に中山間地域に おいては, 労働力人口が転出したため一部の世帯で拡 大家族が維持できなくなり，その後の加龄のため高齢 夫婦世帯および高齢単身世帯が増加した。 高龄夫婦世 帯・単身世帯の割合が高い地域に执いては農村社会の 福祉機能が期待されている.

（2）人口・家族のマク口的側面・ミク口的側面 人口および家族の動向には 1) マク口的, 平均的, あるいは典型的な側面と，2）ミク口的，多元的，あ るいは個別的な側面がある.人口や世帯数は個人ある いは同居世帯員全体を単位とする集合の大きさを示す 数值であり, 通常はかなり大きい母集合の数值の变動 に焦点が当てられる.たとえば，市町村規模の人口に ついてはコーホート残存率を用いて将来推計が可能で あるが，母集団の小さい集落規模のそれは誤差が大き くなるためミクロシミュレーションが有効のように思 われる，家族については，個々の家族があまりにも多 
様なため, 典型的な家族類型や法律的根拠などにもと づて，そして平均的な家族意識の変化から，その変 容にアプローチが試みられてきた．個々の人口事象， 個人，個別の家族，あるいはそれらの関連についてマ ク口的な視点から重要な情報が提供されている.

マクロ的な人口の変動は, 当然のことながら, ミク 口的な個々の出生・死亡・移動・婚姻の人口事象が集 積した結果である．個々の人口事象は世帯あるいは家 族に発生し複数の個人あるい:家族が関与する. 出生 ・死亡は家族の縦の連鎖に，そして婚姻は横の連鎖にか かわる. 個々の人口事象と世帯構成の変化との関係に ついて一年を単位として特定の集落人口について分析 することは，ミクロ的な視点から人口や家族の動態に アプローチするひとつの方法である。また，ミクロ的 な変化をマクロ的な人口変動や家族の変容に関連させ るひとつの方法ともなっている.

\section{（3）地域社会の活性化と人口変動}

人口動態の中でも人口移動と婚姻は地域社会の経済 ・生活水準に影響を受けやすい，農村に拈ける女子の有 配偶出生率は都市にくらべてやや高い程度であり, 平 均寿命は地方差がみられるもののほぼ同一水準にあ る. 一方, 就学・就業機会, 生活のアメニティー, 文 化・悞楽・医療施設へのアクセスなどの地域差は人口 移動の誘因となり，そして長距離交通機関の整備, 情 報通信設備の充実などにより家族ネットワークの機能 に大きな支障を生じることなく自由に居住地を選択す ることが可能となっている. 混住化の時期にみられた 通勤圏にある農村社会の閉鎖性も徐々に開放性を回復 しており，中山間農村においてはI-ターン者の受け入 れを積極的におこなっている。

従って, 地域社会の活性化はその結果として人口の 転入あるい短期滞在人口の増加をもたらすが，他方 で転入人口や短期滞在人口あるいは交流人口の参加を 見込んで地域社会の活性化を図ろらとする同時性がみ られる．地域社会がそれぞれ独自の活性化策を講じれ ば，互いに競合する一面も生じるが，類似する活性化 策の場合とくらべその競合の程度は少ない.100万人 以上の都市の人口が全国人口の約 5 分の 1 を占める現 状において，農村への転出や訪問の需要を全体的に払 大するためには，独自性に富んだ活性化が望まれる． その独自性の追及の過程で, 地域社会への理解・創造 性・協調性・民主性・相互扶助・個性の発揮・自由競 争など, 地域社会のもつ機能の真価が問われている.

地域社会の活性化は多様な側面をもつが，それを人 口再生産の視点と家族の厚生の視点から見直すことが
本論の一つの課題である. 人口再生産の視点からは安 定した人口再生産を保証する環境が求められる. 家族 の厚生の視点からは家族構成員の満足度の充足と家族 全体の厚生の増加が求められる. 実際, 出生・育児, 就学・就業・婚姻, 退職・老後といら個人のライフサ イクル, 家族員・世帯員のライフサイクルの組み合わ せ，そして家族連鎖は互いに重なっているため，より 基礎的と思われる人口再生産の視点を中心にとりあげ る. そして, 人口再生産の視点から地域社会活性化の 課題となる人口の高龄化と未婚化の問題をとりあげ る.

この際, 地域社会活性化がターゲットとする人口や 家族について考える必要があるが，それらは女性人口 ・子供人口・労㗢力人口（シルバーボランティアなどを 含む）・同郷人口・都市人口，さらには世帯が分散し て人口再生産に支障の生じている家族である. 特に, 地域外人口の活用に際しては, 家族ネットワークを利 用し，同鄉人口の人的資源の利用と分散家族のネット ワーク強化を活性化の一つの軸とすることが考えられ る. 同郷ネットワークの利用により地域間の競合も部 分的に分散される.

\section{2. 戦後の人口動態と家族の変容}

\section{（1）人口の動態}

ここで，農村人口の動態の基礎となる全国人口の人 口動態，1）死亡，2）出生，3）移動，4）婚姻に ついてみよ5。普通死亡率は戦時期を除き昭和初期か ら1955年頃まで急速に低下した後，1982年までは緩慢 な低下を示し, その後は人口高齢化の影響を受けて増 加している. 死亡数も増加しており，2020年頃には年 間 150 万人の死亡が予測されている（2000年頃は約 100 万人). 死亡数の変化, 高路人口の割合・世帯構成の 地域差, 高齢者のヶア施設の経済規模・職員確保など の理由から, 地域社会は高龄者に対して異なる対応を 迫られ, 各地域に生じるヶア需給の過不足を広域地域 内で調整する必要が生じる.

死亡水準の指数として年次比較が可能な平均寿命は 継続して改善されており，以前とくらべると個人はよ り長期的でより確実な生涯を送るようになっている. 1994年において，出生から15歳までの生存率は男女と も99\%を超え, 15歳から65歳までの生存率は男子で84 \%, 女子で $92 \%$ となっている. 他方, 65歳時平均寿命 は男子で16年, 女子で20年となり, 高龄期の健康な過 ごし方が重要になっている. 医療や介護の公平な負担 システムの構築と家族の機能へ過度に依存することか 
らの脱却を模索しているのが現状である．この死亡水 準の改善による不確実性の減少之消費超過期間の延長 は, 個人のライフサイクルのみならず家族形成や家族 成員間の関係にも影響を与えている.

死亡水準の低下には多くの要因が貢献している. 直 接には, 医療技術の向上, 医療施設の整備, 栄養摂取 ・衛生管理の向上など, 病気治療 - 予防の進歩が死亡水 準の低下をもたらしている.もちろん, 教育水準の上 昇, 所得の増加, 医療保険制度の確立なぞ社会経済的 要因も関与している. 戦後期の農村においては, 保健 婦や助産婦の活躍, 生活改善・農業改良普及の運動, 婦人会の活動, 妊産婦労働の軽减なども貢献してい る.ただしこれれらの要因は, すべての年齢人口に対 して，均等に死亡水準の低下をもたらしたわけではな い.

出生率についてみると, 戦後から1957年までその顕 著な低下がみられ，丙午にあたる1966年の谷をはさん で1973年までの第二次べビーブーム期には増加がみら れ, その後1990年頃まで再び減少している. 出生数に ついても同様の傾向がみられ, 戦後の一時期, 年間 260万を超えていたそれは，現在120万をで減少してい る. 第三次べビーブーム期には約125万まで増加する と予測されており, その後 2020 年頃には100万を下回 るものと予測されている，女子人口の純再生産率は約 0.7 , 合計出生率は1.5を下回る水準にまで低下してお り，「少子化」の問題としてとりあげられている.

出生数の増减は人口の年龄構成に大きな影響を与兄 る. それは就学人口・新卒労働力人口の増減となり, 教育市場・労働市場の変動要因となる. 日本人口の年 龄構成は, 全体的な出生力の低下と戦後べビーブーム とそのェコーに大きく左右されている．再生産レベル を下回る出生が継続すると, 年少人口割合・労働力人 口割合が減少し, 人口が高龄化する.

出生力の低下については, 供給面と需要面について みる必要がある。供給面についてみると, それは娃娠 中絶および避娃の実行により低下する．農村における 出生力の低下は, 大正・昭和初期から低下傾向にあっ た都市にくらべると少し遅れ，戦後になって顕著にみ られるよらになる。農村に打ける助産婦・保健婦の家 族計画普及活動や婦人会の活動, 優生保護法の改正が 効果を示すようになった，一方，需要面についてみる と, 消費水準の上昇, 進学率の上昇と教育費の増大, 女子貨金の上昇とそれに伴ら家計内生産の機会費用の 上昇, 乳幼児死亡による不確実性の減少により, 人数 からみた子供の「量」の需要は减少し，一人当たりの
養育費からみた「質」の需要は増加した．消費水準の 上昇と子供の養育費の増大に伴い, 家族の家計経営能 力の強化と情報提供システムの整備が望まれる. 家族 を取り巻く環境条件の変化の中で「少子化」が選択さ れて括り，家族のもつ多様な機能が質的な側面および 経済効率の側面から摇り動かされている.

出生と死亡が閉鎖人口の年龄構造を決定するのに対 し, 地域人口のように社会移動に開放された人口の場 合にはそれらに加えて人口移動が年龄構造を決定す る. 1955年から1970年までの間に年間40万人を超える 常住人口の純移動が全国13地域と三大都市圏との間で みられる. その後, 賃金格差および雇用機会や教育機 会の格差に対応した就職・就学に伴ら若年人口の転出 が，農村人口の高龄化をより顕著にする結果となっ た. 地域によっては挙家離村を伴い, 農村社会として の機能を失う場合も生じた.人口移動により家族が分 散し, 都市へ転出した家族成員の行動が都市化した ク，マスメディア以外に都市に関する情報源をむつこ とになり，農村社会にも影響を与えることとなる。そ れは，婚姻圏の拡大にも影響を与えたものと推測され る.

平均初婚年龄の增加, 婚姻率の低下，未婚率の上 昇, 離婚率の上昇が戦後の一般的な傾向としてみられ るが, 戦中戦後の婚姻ブームとべビーブーム世代の結 婚市場への参入は擋乱的な影響を与えている. 高龄未 婚者の割合が低いことから，今までは皆婚状況にあっ たと考兄られる.しかし，1950年と1995年とを比較す ると，25-29歳女子人口の未婚者割合は15\%から49\% へ，30-34歳男子人口のそれは $8 \%$ から37\%へと上昇 している. 50歳時の未婚者割合も男女とも $2 \%$ 以下か ら女子 $5 \%$, 男子 $9 \%$ 以上へと増加しており, 今後も 増加を続けるものと予測される。

農村人口についてみても同様の未婚化の傾向がみら れるが，全国トレンドと比較して，女子については全 体的に未婚割合が低く男子については一部の地域でそ れが高くなる傾向がみられる.女子人口については初 婚年龄の上昇がみられるものの35歳以上人口について は皆婚状況に大きな变化がみられない, 他方, 男子人 ロについては35歳以上について未婚化が進んでおり， 家族形成に支障の生じる可能性がみられる. 㹟い婚姻 圈内では局所的に男女可婚人口に不均衡が生じてお り，「嫁不足」や「婿不足」の状況がみられる.

未婚化および非婚化は結婚の需要および供給の低下 （結婚希望者減少の二側面）により生じているが，そ れは個人の生活や家族の変容を反映している. 子供の 
需要や独身生活のコストが低下したこと, 家計内生産 に拈ける女性の機会費用が上昇したことなどが影響し ている. しかし，農村の家族形成に拄いては女子人口 についてみる限りこのような変化が非婚化に影響を与 えているとは思われない，男子人口については，地域 外から配偶者が婚入する場合と, 本人が地域外一婚出 する場合が考兄られる．都市に居住する未婚女性との 婚姻と農村居住が成立するためには，婚姻のメリット を高め交流の機会を增やす必要が生じる.

人口の動態についてみてきたが，最後に人口が减少 することの含意についてみよう．幼稚園の縮小・廃業 や助産婦の減少など, 人口の絶対数の減少は社会経済 に大きな影響を及ぼす、ベビーブームとその後の低出 生力化により影響を受けた釣り鐘型の人ロピラミッド も三角ピラミッド型の企業組織に変更を促した一つの 要因である. 人口が減少する場合には，消費需要・資 産・眝蓄の縮小など経済規模の縮小，企業の統廃合， 再編成, 労働力確保のための競争が生じる. 人口が増 加している時期にくらべ，减少する際の対応について の経験はそれほど蓄積されていない，農村はこの点で 先進地域ではあるが，余㮃労働が都市や工業地域に吸 収された経験はそれほど有効ではない，これからは， 労働生産性の維持・向上のための新規企業の創設に加 兄既存企業の統廃合・再編成が不可欠となる. 後継者 確保の困難な農家や兼業農家のみならず，専業農家や 農企業にも競争的な経営戦略が要求される. 農家に対 しては, 家族としてそして農企業として経営能力の強 化が求められている.

\section{(2) 家族の変容}

戦後の新憲法や改正民法は人権および機会の平等を 強調しているが，新しい規則を受け入れながらも古い 慣習と位置づけられることとなったイエ制度や家督に 固執する人々もいた．敬老，年功，報恩などの心情は 急速に薄れるものではない。このような情緒は家族の 機能, 農村社会の互助性, 階層組織, 長期的な関俰維 持に有効に働く.

産業構造は高度経済成長期を通じて大きく变化し， 第 1 次産業就業人口割合は地域別に大きな差があるも のの1995年には全国平均で $6 \%$ にまで減少した，男女 とも被雇用者割合が增加し，家族生活において家計内 生産以外の生産活動と消費活動が分離していった。

高度経済成長期に，農村の家族は長子や結婚の可能 性の高い女子を除く余㮃労働力を都市や工業地帯へ送 クだした. 後継にかかわる長子の転出や挙家離村も生 じた．血縁や地縁で結ばれた農村社会から解放された
都市の新しい住人は，比較的自由な生活に慣れるよう になる。

洗䍜機, 炊飯器, 冷蔵庫などの電化製品が家事労働 時間を大幅に縮小したことは重要で，家計内生産の労 働生産性が上昇した．テレビの普及は娛楽の費用を引 き下げたことになる．家事労働時間の大幅な減少は， 稼得者が一人の核家族世帯に打いて，夫は仕事，妻は 家事, 子供は勉強といら明確な分業を可能にするるの であった．核家族世帯において夫が家事や子供の養育 をほとんど手伝っていない状況は，1991年の『社会生 活基本調査』からも示される.

労㗢市場に护ける労㗢生産性がさらに上昇すると, 家計内生産においてもそれに応じた労㗢生産性の上昇 が求められた. 電子レンジ, 皿洗い機, 衣類乾燥機, 個人消費用の食材セット，警備システム，コンビニな どはその例である.これらの設備や機材は家計内生産 に拈ける労働生産性の男女格差を縮小したため, 結婚 からえられる恩恵も縮小した．他方，30歳代の男子未 婚者割合が增加し，夫子をもつキャリア女性の活羅が みられるよらになり，個人の能力や責任感を配偶関係 によって判断することは有効性を失った。

経済成長と高い生活水準の達成に伴い，家族成員間 の経済関係が变化してきたことは明らかである．経済 発展に伴い家族の保険的機能を代替する社会保障制度 も充実してきており，個人の経済的自立や自助努力， そして家族成員間の相互扶助の重要性や一蓮托生的な 情緒が変化していることは否めない。

長子相続のもとでは，老親の扶養は長男夫婦に期待 されて招り，親子両者ともその意識の変化には時間が かかっている. 权たきり老人人口が増え，その期間が 延長され，介護する家族員の年龄が高齢化し，介護に あたる子供の数が減少しているため, 財政的に健全で 広範かつ集中的な公共サービスが必要とされている.

家族内で介護を受けもつ人の機会費用が上昇したた め，自宅介護サービスの費用も高額になっている，老 親が介護サービスに見合らだけの資産をもたない場 合，その費用は子供の負担となる。このことが親子間 や子供間に家族争議を生じさせる理由ともなってい る.

払大家族世帯において家族成員は，一方で同居のコ ストとしてプライバシーと独立した生活を犠牲にする ものの，他方でそのべネフィットとして比較的緊密な 家族関係と規模の経済を得ることができる，たとえ ば，子供をもつ母親でも祖父母に子供を預けて就業活 動を続けることができる．専用託児所を家計がもつこ 
とにより, 祖父母の労働生産性も上昇する. 一方, 都 市部では, 自由な生活を拉くる単身世帯の独身貴族 や，親元に身を怙きながらも給与の大部分を自由に処 分できる核家族世帯の中の独身貴族が増加している.

独立した意思決定主体である個人の利害が調整され ない限り，家族の共同意思決定（合意形成）はなされ ない，家族の慣行も，それが宗教的であるか否かを問 わず，個人の参加と実行に依存している。一方，家族 は家族成員間の心情的に親密な関係のみならず経済的 にも相互依存的な関係である。家族の内部において， 分業, 協同生産, 共通消費, 相互信用の賦与, 所得移 転, および知識の移転を通じて経済的にも緊密な関俰 を維持しているのである. 地域社会活性化のために， このよらな家族の機能を利用することも考えられる.

\section{（3）晨村人口・家族の特徵}

戦後の農村人口の推移は, 上述のよ5に変動要因が ある程度共通しており, 地域差はあるもののほぼ類似 した経過をたどる．戦後の引き揚げ人口の帰郷は疎開 人口のそれを上回り，一時的な人口増加が生じる.そ の後, 高度経済成長期に都市・工業地域に人口が転出 し，人口／土地比からみた過蹯化が進行する. 転出人 口の多くは若年労働力であり, 農村は都市・工業地域 へ労働力人口を供給する人口排出基地の役割を果た す. 戦後の出生数の減少と若年労働力人口の流出は, 人口の年龄構成にくびれを生じさせ，一世代経過後 （1990年頃）には人口の高龄化が顕著となる．二世代 経過時までには「超」高齢社会を迎え，その後に高龄 安定人口期に入ることが予測される.

農村の世帯の家族構成の特徵は, 核家族世帯の増加 が顕著にみられないことである．直系扗大家族世帯の 割合が高く比較的安定した家族形成が継続している.

都市へ転出した家族成員が核家族世帯を形成したこと にくらべ，農村において積極的に核家族世帯を形成す ることは一部の地域を除いてそれほど顕著にはみられ ない。一方, 一部の中山間地域では子供世代が転出し たため扗大家族世帯を維持できなくなり, 高齢夫婦世 帯や単身世帯が目立つようになっている. 農村の家族 の厚生について考学る限り, 都市の核家族世帯や単身 世帯とは異なるアプローチが必要である。他方，交流 人口や I ・ J ・ U ターンの対象は主に都市の核家族世 帯や単身世帯であり, 農村の払大家族世帯の一部を構 成する場合も含まれる。

\section{（4）人口動態・世帯構成変化の接点}

世帯は家族員の続柄の組み合わせに応じて分類する ことが可能で, 出生・死亡・転出・転入が発生する
と，それは類型区分間を推移する．30戸から200戸程 度の規模をもつ集落の各世帯を継時的に追跡するパネ ルデータを整備することにより, 人口・世帯の特徵を 把握することが可能となる. 推移前の類型区分を行, 推移後のそれを列とする行列のセルに, 出生・死亡・ 転入・転出のヶース数を示すと，人口事象と世代間推 移の関係を示寸行列が得られる。これにより, 地域間 の比較扣よび地域内集落間の比較が可能となる.

\section{3 . 人口再生産の視点}

発展途上国の貧困・難民・過鄱人口・人口集中など の問題と日本の少子化や高齢化の問題とは，一見，大 きくかけ離れた別世界の問題のよ5に思われる. マル サスは人口の相対的に過大な増加力が人口問題の根源 であるとしたが，個人の意思によって出生の制限が可 能な現在の先進国に拈いて人口問題を問いかける場 合, あらたな視点からのアプローチが求められる.

人口の変動には夫婦・親子の家族連鎖が出生・死亡 ・移動・婚姻を通じて伸展する一面がある．多くの世代 が重層するなかで, 出生により新たな世代が追加され 死亡により年老いた世代が退出する過程は人口が再生 産される過程として認識することがでさる．この人口 再生産の視点は, マルサスの人口問題へのアプローチ の原点に近づくものとも考兄られるが，途上国につい ても先進国についても過㮃・適度・過少を検討するた めの分析枠組みを構筑するための基礎となる．たとえ ば，過眯問題は，人口が流出することに伴ら問題であ る一方, 少ない経済機会に対して過剩な人口の問題で もある．与えられた経済条件のもとで安定した家族形 成と人口再生産が可能となるような地域活性策を展開 する必要がある.

そのためには，家族の経済機能について整理してお。 く必要がある。しかし，家族には特異な経済主体の側 面があり，個々の家族成員の意思決定とのかかわりを 明確にする試みがなされているのが現状である，第一 に, 家計内生産と家族成員の分業・協業があげられ る．自家消費する農家の経済モデルと家計内生産モデ ルとは類似している，それは女子の就業・結婚・出生 の分析に用いられる。

第二に，ゲーム論的な家族成員間の相互作用があげ られる. 家計内生産の資源配分就上び生産物の分配に かかわり，与えられた規則や制約条件と個人の選好構 造とに依拠する，家族成員間の相互作用には，家族成 員の多様な反応以外飞, 家族の厚生, 共同意思決定, 共通制約条件, 利他的効用などが関わる. 
第三に家族連鎖と世代間所得移転があげられる．家 族は親子関係と配偶関係の連鎖であるが，その間で所 得移転が生じる. 相続に伴ら資産の移転もこれに含ま れる、稼得能力のない乳幼児の養育は親の義務である 一面をるつが，それは養育のサービスを含む親から子 への所得移転である。また，老親の扶湌および介護は 子から親への所得移転である. 家計内生産物の大部分 が家計内で消費されるため, 家族は内部市場の機能を もつことに注意を要する.

第四に家族は保険機能をむつことがあげられる．家 族成員間の所得移転は長期契約の履行の側面をもつ が，それとともに成員の失敗や事故に伴う負債を共有 する傾向が強い，社会保障システムが完備されていな い場合，子供の養育は老後のための保険の掛け金にあ たるものとも考えられる。

家族の経済合理性は農家にも該当し, 地域経済から みた農業生産の経済効率が低い場合でもそれを与件と して最適化を図っているものと考えられる．労働生産 性からみて余剩な労働力は雇用機会を求めて都市へ転 出したり兼業化した. 農作業が規格化し比較的安定し た価格が得られる稲作に多くを依存している.

家族の機能以外に人口再生産の視点にかかわる要素 として1）ライフサイクル消費配分，2）世代間およ び世代内の経済的公正，3）長期的視野と短期的対応 をあげることができる.ライフサイクルモデルでは生 涯所得を一生の間に配分する個人の経済合理性がとり あげられ，所与の所得プロフィールと解としての消費 プロフィールが示される. 生涯所得と生涯消費の大 小, 年龄別の所得と消費の大小, 所得移転, 眝蓄 - 投 資・年金システムの存在，家族の役割などについて検 討する際の一つの根拠をそれは与えている.

世代間打よび世代内の経済的公正は生産の効率と分 配の公正にかかわる問題である. 家族や財政システム をつらじて所得移転が実施されるが，人口が縮小寸る 中で健全な経済運営を保証するような世代間の所得分 配, 貯蓄の維持, 物的扰よび人的投資効率の確保が必 要となる，経済システムと所得移転のために世代内・ 世代間の協力が必要であると同時に，世代毎に独立採 算の収支が保たれる必要がある。家族が親子の間で所 得・資産の分配を公正にする機能を果たすと仮定すれ ば，親子連鎖が継続する限りにおいて，財政政策によ る所得移転が特定の世代に偏っても，それは世代間の 公正を保とうとする機能を果たす.

安定人口のよ5に人口動態率が一定の場合，世代間 の分配は平均的な経済成長率を基本にして考えられる
が, ベビーブームの影響による世代別人口の大小や非 婚化・少子化が生じる場合, 長期的視野と短期的対応 が必要となる. 短期的には世代毎の独立採算が保たれ なくても長期的には各世代が経済成長からの恩恵をよ り多く得られる場合があり得るからである.

\section{4. 農村社会の人口問題と政策形成 一むすびにかえて}

本論では, 農村人口の動態と家族の変容についてそ の外観をとらえ, 基本的な人口再生産の視点について 説明を加えた．1）過渡的で局所的な超高齢化社会, 2 ）男子未婚者割合の増加，3）人口減少，4）人口 再生産のための社会資本の整備と地域了メニティーの 向上などの課題を地域社会活性化の諸策の中に位置づ ける必要のあることはいらまでもない，地域差のみら れる人口の動態と家族の変容を把握した上で, 常住世 帯の家族成員の厚生の増加, より広くいえば地域住民 の厚生の増加に結びつく政策オプションを用意する必 要がある.

その政策オプションには，家族形成に焦点をあてた 地域活性化策, 異なる世代間の平等と助け合いをめざ した地域活性化策, 女性にとって魅力のある地域活性 化策が含まれ，行政・地域社会・家族が互いの機能を 補完する必要がある.より一般的に, 独創的な地域社 会活性化を進めるためには，政策オプションを提言す るタスクフォースの活動が必要で, 住民意識の把握・ 高揚, 地域資源や中央行政についての情報收集などが 不可欠である．同様に，県などの広域行政レベルでる 地域社会活性化のサポートとなる発案・調整・パイプ 役のタスクフォースが必要となる.このよらな課題を 抱光る地域社会にとってはより広い人的資源の活用が 有効で，地域間ネットワークのみならず，家族ネット ワークを媒介とする同郷人口をより組織的に地域社会 の活性化に参画・参加させる必要がある.

\section{参考文献}

国立社会保障・人口問題研究所『人口統計資料集1997』1997 年.

柏祐賢, 坂本慶一『戦後農政の再検討』ミネルヴ $、$ 書房1978 年.

河村能夫「農村活性化を考兄る基本的枠組み」『農業と経済』 1991年 1 月.

松下敬一郎「結婚の経済分析について」『人口問題研究』第 180 号1986年.

- 'Economic Implication of the Aging of the Labour Fource, ' Economic and Social Implications of Population 
Aging, United Nations, 1988.

'Economic Analysis of Age at Marriage, 'Journal of Population Economics, 2 (2), 1989.

一「農村の家族」『人間にとって農業とは』学陽書房 1989年.

一「小地域人口・世帯の比較分析」『地域総合研究』 第 2 号1991年.

一「農村社会の経済変動」『統計』1994年 3 月. 「人口問題への提言」『南陽市の人口問題研究』南 陽市まちづくり研究会1996年

'Changing Japanese Families, An Economist's View, 'A Glimpse of Japanese Culture, University of Colombo, 1997.

「南陽市の人口の特徵」『人口とまちづくり』南陽 市1997年.

松下敬一郎・松田武志「地域人口の特徵一西川町の事例」『地
域総合研究』第 6 号1996年.

Becker, G.S., A Treatise on the Family, Harvard University Press, 1981.

Blinder, A.S., 'Intergeneration al Transfers and Life Cycle Consumption, American Economic Review, 66 (2), 1976.

Feldstein, M., 'Social Security, Induced Retirement, and Aggregate Capital Accumulation,' Journal of Political Economy, 82 (5), 1974.

Kotlikoff, L.J. and A. Spivak, 'The Family as an Incomplete Annuities Market,' Journal of Political Economy, 89 (2), 1981.

Samuelson, P.A., 'An Exact Consumption-Loan Model of Interest with or without the Social Contrivance of Money,' Journal of Political Economy, 66, 1958.

（著者：龍谷大学社会学部） 